\title{
First-Line Management of Advanced High-Grade Serous Ovarian Cancer
}

\author{
Reem D. Mahmood ${ }^{1} \cdot$ Robert D. Morgan ${ }^{1,2} \cdot$ Richard J. Edmondson $^{2,3} \cdot$ Andrew R. Clamp $^{1} \cdot$ Gordon C. Jayson ${ }^{1,2}$
}

Published online: 4 June 2020

(C) The Author(s) 2020

\begin{abstract}
Purpose of Review Epithelial ovarian cancer is a disease that encompasses a number of histologically and molecularly distinct entities; the most prevalent subtype being high-grade serous (HGS) carcinoma. Standard first-line treatment of advanced HGS carcinoma includes cytoreductive surgery plus intravenous paclitaxel/platinum-based chemotherapy. Despite excellent responses to initial treatment, the majority of patients develop recurrent disease within 3 years. The introduction of the vascular endothelial growth factor (VEGF) inhibitor, bevacizumab, and poly(ADP-ribose) polymerase (PARP) inhibitors into first-line management has changed the outlook for this lethal disease. In this review, we summarise the most recent clinical trials that determine current primary therapy of advanced HGS carcinoma and the ongoing trials that aim to change management in the future.

Recent Findings Recent phase III clinical trials have shown that delayed primary surgery after completing neo-adjuvant chemotherapy is non-inferior to immediate primary surgery, but could provide a survival benefit in FIGO (International Federation of Gynecology and Obstetrics) stage IV disease. The use of weekly intravenous chemotherapy regimens has not been proven to be more effective than standard 3-weekly regimens in Western patient populations, and the use of intraperitoneal chemotherapy remains controversial in the first-line setting. In contrast, newer systemic anti-cancer therapies targeting angiogenesis and/or HRdeficient tumours have been successfully incorporated into front-line therapeutic regimens to treat HGS carcinoma. Recent results from randomised trials investigating the use of PARP inhibitors as monotherapy and in combination with the antiangiogenic agent, bevacizumab, have demonstrated highly impressive efficacy when combined with traditional first-line multi-modality therapy.

Summary Management of HGS carcinoma is evolving, but further work is still required to optimise and integrate tumour and plasma biomarkers to exploit the potential of these highly efficacious targeted agents.
\end{abstract}

Keywords Ovarian cancer $\cdot$ Bevacizumab $\cdot$ PARP inhibitors $\cdot$ Cytoreductive surgery $\cdot$ Intra-peritoneal chemotherapy

\section{Introduction}

Ovarian cancer is the 8th commonest cancer diagnosed in women and the 8 th commonest cause of female cancer-

This article is part of the Topical Collection on Gynecologic Cancers

Gordon C. Jayson

Gordon.Jayson@christie.nhs.uk

1 Department of Medical Oncology, Christie NHS Foundation Trust, Wilmslow Road, Withington, Manchester M20 4BX, UK

2 Faculty of Biology, Medicine and Health, University of Manchester, Manchester, UK

3 Department of Gynaecological Oncology Surgery, Saint Mary's Hospital, Manchester University NHS Foundation Trust, Oxford Road, Manchester, UK related death worldwide [1]. Approximately 300,000 women were diagnosed with ovarian cancer in 2018 [1]; the majority being diagnosed with FIGO (International Federation of Gynecology and Obstetrics) stage III/IV disease [2, 3]. Ovarian cancer originates from the epithelial cells (ovarian surface/distal fallopian tube epithelium) in around $90 \%$ of cases, with the histological subtype high-grade serous (HGS) accounting for $70 \%$ of cases [4]. Standard first-line treatment of advanced HGS carcinoma involves cytoreductive (debulking) surgery with paclitaxel/platinum-based chemotherapy $[5,6]$. Despite excellent initial treatment responses in around $70 \%$ of women, the majority of patients develop recurrent disease within 3 years of their primary therapy [7].

First-line treatment for advanced stage HGS carcinoma provides the only realistic opportunity for cure, with a 5-year survival of $27 \%$ in patients with FIGO stage III disease [8]. In 
women whose disease is not cured, first-line treatment often leads to the longest disease-free interval (DFI), allowing for the greatest time period to regain quality of life during the disease. For these reasons, research has focused on therapeutic strategies that optimise outcomes of primary therapy. This review summarises the key clinical trial data that have led to the current status of first-line treatment of advanced HGS carcinoma.

\section{Primary Cytoreductive Surgery}

Primary cytoreductive surgery allows for accurate FIGO staging and should be directed towards achieving complete debulking (i.e., no residual disease [RD]) [9, 10]. Traditionally, immediate primary surgery (IPS) was performed followed by adjuvant platinum-based chemotherapy. However, a proportion of women diagnosed with advanced stage disease are unable to undergo IPS due to contra-indications, including comorbidities and/or disease-related factors e.g. tumour burden [11]. For these patients, delayed primary surgery (DPS) after completing 3-4 cycles of platinum-based neoadjuvant chemotherapy (NACT) was demonstrated as a non-inferior therapeutic option in two randomised phase III trials by comparison of the primary outcome of overall survival (OS) $[12,13]$. In the EORTC 55791 trial, 632 women diagnosed with FIGO stage IIIC-IV epithelial ovarian cancer (EOC) (61.8\% serous adenocarcinoma) were randomised to undergo either IPS followed by at least 6 cycles of adjuvant platinum-based chemotherapy versus 3 cycles of platinum-based NACT followed by DPS and a further 3 (or more) cycles of adjuvant chemotherapy [12]. In the CHORUS trial, 550 women diagnosed with FIGO stage IIIA-IV EOC ( $70.5 \%$ HGS) were randomised to undergo IPS followed by 6 cycles of adjuvant platinum-based chemotherapy or 3 cycles of platinum-based NACT followed by DPS and a subsequent 3 cycles of chemotherapy [13]. There was no difference in overall survival (OS) between groups in either trial (EORTC 55791: HR 0.98, 95\% CI 0.84-1.13; CHORUS: HR 0.87 95\% CI 0.72-1.05). However, in a subsequent metaanalysis including individual patient data from both trials, patients diagnosed with FIGO 1988 stage IV disease had significantly improved OS (24.3 versus 21.2 months, HR 0.76 , 95\% CI $0.58-1.00, p=0.048$ ) if they were treated with NACT followed by DPS [14•]. Both EORTC 55791 and CHORUS demonstrated that peri- and post-operative morbidity/ mortality occurred less frequently in those women undergoing NACT-DPS $[12,13]$.

EORTC 55971 and CHORUS have been criticised due to the low number of patients in whom surgery achieved complete cytoreduction at IPS; debulking to less than $1 \mathrm{~cm}$ of residual disease was achieved in $42.3 \%$ of patients in EORTC 55971 and $41.6 \%$ of patients in CHORUS $[12,13]$.
As a result, TRUST (NCT02828618) was initiated, which is an ongoing randomised phase III trial recruiting women diagnosed with FIGO stage IIIB-IVB EOC within quality-assured gynaecological oncology centres that fulfil certain criteria including that they carry out more than 36 debulking surgeries a year, achieve complete cytoreduction in $\geq 50 \%$ of cases and are willing to undergo audits from the TRUST committee to verify these numbers [15]. Nevertheless, EORTC 55971 and CHORUS led to the paradigm shift in clinical practice, in which DPS is now routinely considered in patients unlikely to achieve no RD/complete cytoreduction with IPS and those with comorbidities indicating high peri-operative morbidity/ mortality risk $[5,6]$. Factors which impact on the ability to achieve complete cytoreduction include extra-abdominal metastases, extensive bowel involvement or complex blood vessel involvement $[16,17]$.

During primary cytoreductive surgery, the removal of bulky or suspicious lymph nodes is part of complete cytoreduction. However, complete pelvic lymph node resection at time of surgery is not currently recommended [6]. Retrospective analysis had suggested an OS benefit with complete systematic pelvic and para-aortic lymphadenectomy [18, 19]. A phase III trial then showed that systematic resection of pelvic and para-aortic lymph nodes compared to resection of bulky lymph nodes only did not provide a survival benefit. But this trial was criticised due to the inclusion of patients with complete resection and residual disease up to $1 \mathrm{~cm}$ after surgery [20]. The phase III LION trial was set up to determine if systematic lymph node dissection prolongs OS with a more homogeneous group of patients [21•]. Women $(n=647)$ were recruited with diagnosed FIGO stage IIB-IV EOC and were randomly allocated intraoperatively to proceed to complete lymphadenectomy or not if they met the following criteria: achieved complete macroscopic resection, intraoperatively remained in good condition and had no clinically positive lymph nodes. The study showed that systematic lymphadenectomy increased detection of sub-clinical retroperitoneal metastases in $56 \%$ of patients but was not associated with improved OS (69.2 versus 65.5 months, HR 1.06, 95\% CI $0.83-1.34)$. Systematic lymphadenectomy did increase postoperative morbidity and mortality [21•]. The results from the LION trial confirm guidelines from the European Society of Medical Oncology (ESMO) that lymph node resection at primary surgery should focus only on nodes that are suspected to harbour metastatic disease [6].

\section{Dose-Dense First-Line Chemotherapy}

Standard first-line chemotherapy for EOC includes 3-weekly platinum and 3-weekly paclitaxel chemotherapy $[5,6]$. In the United Kingdom (UK), guidance from the National Institute for Health and Care Excellence (NICE) also currently 
recommends to offer single-agent platinum-based chemotherapy as an alternative to combination regimens [22]. Dosedense regimens involve weekly administration of chemotherapy. Indeed, preclinical data showed that metronomic scheduling of docetaxel or paclitaxel was effective [23], and early phase trial data supported the evaluation of dose-dense taxanes within randomised phase III trials [24-27]. Four randomised phase III trials have been reported investigating dose-dense first-line therapies (Table 1) [28-31].

In JGOG 03016, 631 women diagnosed with FIGO stage II-IV EOC (55.7\% serous adenocarcinoma) were recruited from 85 centres in Japan. Women were randomised to 3weekly carboplatin (AUC6) and weekly paclitaxel $(80 \mathrm{mg} /$ $\mathrm{m}^{2}$ ) versus 3-weekly carboplatin (AUC6) plus 3-weekly paclitaxel $\left(180 \mathrm{mg} / \mathrm{m}^{2}\right)$ [28]. JGOG 03016 reported a significant improvement in PFS (28.0 versus 17.2 months, HR $0.71,95 \%$ CI $0.58-0.88$ ) and OS (100.5 versus 62.2 months, HR 0.79 , $95 \%$ CI $0.63-0.99, p=0.39$ ) in the dose-dense weekly paclitaxel arm $[28,32]$. Similar toxicity profiles were reported in each treatment arm, although the prevalence of myelosuppression was greater in the dose-dense arm and negatively impacted on the ability to complete the target 6 cycles of chemotherapy (Table 2) [28]. The results from this trial were encouraging, although additional data was required to determine if the trends were reproducible within different ethnic populations.

Three randomised phase III trials have since been reported investigating dose-dense therapy in European (MITO-7, ICON8) and North American (GOG 262) populations [29-31] (Table 1). In MITO-7, 822 women, from Italy or France, diagnosed with FIGO stage IC-IV EOC (69.6\% serous adenocarcinoma) were randomly allocated to receive either 3-weekly carboplatin (AUC6) plus 3-weekly paclitaxel $\left(175 \mathrm{mg} / \mathrm{m}^{2}\right)$ or weekly carboplatin (AUC2) plus weekly paclitaxel $\left(60 \mathrm{mg} / \mathrm{m}^{2}\right)$ [29]. In ICON8, 1566 women, from the UK, Ireland, Australia, New Zealand, Mexico or South Korea, diagnosed with FIGO stage IC-IV EOC (68.5\% HGS) were randomised to receive either 3-weekly carboplatin (AUC5/6) plus 3-weekly paclitaxel $\left(175 \mathrm{mg} / \mathrm{m}^{2}\right)$ or one of two experimental arms: 3-weekly carboplatin (AUC5/6) plus weekly paclitaxel $\left(80 \mathrm{mg} / \mathrm{m}^{2}\right)$ or weekly carboplatin (AUC2) plus weekly paclitaxel $\left(80 \mathrm{mg} / \mathrm{m}^{2}\right)$ [30••]. Neither MITO-7 nor ICON8 showed an improvement in PFS in the dose-dense experimental arms [29, 30] (Table 1).

In GOG 262, 692 North American women diagnosed with FIGO III-IV incompletely resected at IPS or FIGO II-III with residual lesions $\leq 1 \mathrm{~cm}$ after IPS EOC ( $88 \%$ serous adenocarcinoma) were randomised to receive 3 -weekly carboplatin (AUC6) with either 3-weekly paclitaxel $\left(175 \mathrm{mg} / \mathrm{m}^{2}\right)$ or weekly paclitaxel $\left(80 \mathrm{mg} / \mathrm{m}^{2}\right)$ [31]. In addition, all patients were given the option of incorporating the anti-angiogenic agent, bevacizumab $(15 \mathrm{mg} / \mathrm{kg}$; 3-weekly from cycle 2 until disease progression or intolerable adverse event). In total, $84 \%$ of
Table 1 PFS outcomes from first-line, phase III dose-dense chemotherapy trials [28-31]

\begin{tabular}{|c|c|c|c|}
\hline \multirow[t]{2}{*}{ Trial } & \multicolumn{3}{|l|}{ PFS (months) } \\
\hline & $\begin{array}{l}\text { 3-weekly } \\
\text { carboplatin and 3- } \\
\text { weekly paclitaxel }\end{array}$ & $\begin{array}{l}\text { 3-weekly } \\
\text { carboplatin and } \\
\text { weekly paclitaxel }\end{array}$ & $\begin{array}{l}\text { Weekly } \\
\text { carboplatin and } \\
\text { weekly } \\
\text { paclitaxel }\end{array}$ \\
\hline JGOG3016 & 17.5 & $\begin{array}{l}28.2 \\
\text { (HR } 0.76,95 \% \\
\quad \text { CI } 0.62-0.91 \\
p=0.0037)\end{array}$ & N/A \\
\hline MITO-7 & 17.3 & N/A & $\begin{array}{l}18.3 \\
\text { (HR } 0.96,95 \% \\
\quad \text { CI } 0.80-1.16 \text {, } \\
p=0.66)\end{array}$ \\
\hline ICON 8 & 17.7 & $\begin{array}{l}20.8 \\
(p=0.35)\end{array}$ & $\begin{array}{l}21.0 \\
(p=0.51)\end{array}$ \\
\hline $\begin{array}{l}\text { GOG } 262 \\
+\begin{array}{l}\text { 3-weekly } \\
\text { bevacizu- } \\
\text { mab }\end{array}\end{array}$ & 14.0 & $\begin{array}{l}14.7 \\
\text { (HR } 0.89,95 \% \\
\quad \text { CI } 0.74-1.06, \\
p=0.18)\end{array}$ & N/A \\
\hline
\end{tabular}

The initial JGOG trial showed an advantage to dose dense chemotherapy but this was not confirmed in subsequent randomised trials (MITO-7, ICON8 and GOG 262). In addition, currently ongoing is the ICON 8B trial which is comparing weekly chemotherapy regimens with 3 -weekly regimens, with concurrent bevacizumab $(7.5 \mathrm{mg} / \mathrm{kg}) 3$-weekly for a maximum of 22 cycles. The primary outcomes of ICON8B are PFS and OS

patients recruited to the trial chose to receive bevacizumab. In keeping with MITO-7 and ICON8, GOG 262 showed no significant difference in PFS between arms (14.7 versus 14.0 months, HR $0.89,95 \%$ CI $0.74-1.06$ ) [31].

Tolerability of weekly dose-dense chemotherapy differed between MITO-7, ICON8 and GOG 262 (Table 2) in that fewer patients who received weekly treatment had grade 3 or more neutropenia in MITO-7 and GOG 262, whereas the opposite was reported in ICON8. Moreover, the prevalence of grade 2 or more neuropathy was lower in patients receiving weekly treatment in MITO-7, higher in GOG 262, but not different in ICON8. The dose-dense MITO-7 regimen, which incorporated a lower dose of weekly paclitaxel to the other studies $\left(60 \mathrm{mg} / \mathrm{m}^{2}\right.$ versus $\left.80 \mathrm{mg} / \mathrm{m}^{2}\right)$, was tolerated better by patients, and patients reported significantly better quality of life scores than those on 3-weekly treatment. This could justify the use of this regimen in patients with advanced stage disease and poorer performance status (i.e. 3 to 4 ). Weekly carboplatin (AUC2) plus paclitaxel $\left(60 \mathrm{mg} / \mathrm{m}^{2}\right)$ is recommended by the National Comprehensive Cancer Network $(\mathrm{NCCN})$ for patients with a poorer ECOG (Eastern Cooperative Oncology Group) performance status or for use in patients $>70$ years old and/or those with comorbidities (e.g. renal disease) [5]. However, all trials limited inclusion criteria to those with an ECOG performance status of 2 or less, so tolerability of weekly regimens may not be translated clinically to other subgroups of patients [33]. 
Table 2 Toxicities reported in dose-dense chemotherapy trials [28-31]

\begin{tabular}{|c|c|c|c|c|c|c|c|c|c|}
\hline \multirow[t]{2}{*}{ Trial } & \multicolumn{2}{|l|}{ JGOG3016 } & \multicolumn{2}{|l|}{ MITO-7 } & \multicolumn{3}{|l|}{ ICON8 } & \multicolumn{2}{|l|}{ GOG 262} \\
\hline & $\begin{array}{l}\text { 3-weekly } \\
\text { carboplatin } \\
\text { and 3- } \\
\text { weekly } \\
\text { paclitaxel }\end{array}$ & $\begin{array}{l}\text { 3-weekly } \\
\text { carboplatin } \\
\text { and weekly } \\
\text { paclitaxel }\end{array}$ & $\begin{array}{l}\text { 3-weekly } \\
\text { carboplatin } \\
\text { and 3- } \\
\text { weekly } \\
\text { paclitaxel }\end{array}$ & $\begin{array}{l}\text { Weekly } \\
\text { carboplatin } \\
\text { and weekly } \\
\text { paclitaxel }\end{array}$ & $\begin{array}{l}\text { 3-weekly } \\
\text { carboplatin } \\
\text { and 3- } \\
\text { weekly } \\
\text { paclitaxel }\end{array}$ & $\begin{array}{l}\text { 3-weekly } \\
\text { carboplatin } \\
\text { and weekly } \\
\text { paclitaxel }\end{array}$ & $\begin{array}{l}\text { Weekly } \\
\text { carboplatin } \\
\text { and weekly } \\
\text { paclitaxel }\end{array}$ & $\begin{array}{l}\text { 3-weekly } \\
\text { carboplatin and } \\
3 \text {-weekly } \\
\text { paclitaxel } \pm 3 \text { - } \\
\text { weekly } \\
\text { bevacizumab }\end{array}$ & $\begin{array}{l}\text { 3-weekly } \\
\text { carboplatin and } \\
\text { weekly } \\
\text { paclitaxel } \pm 3 \text { - } \\
\text { weekly } \\
\text { bevacizumab }\end{array}$ \\
\hline \multicolumn{10}{|l|}{ Toxicity } \\
\hline $\begin{array}{c}\text { Grade 3-4 } \\
\text { anaemia }\end{array}$ & $44 \%$ & $69 \% *$ & $8 \%$ & $6 \%$ & $5 \%$ & $13 \% *$ & $5 \%$ & $16 \%$ & $36 \% *$ \\
\hline $\begin{array}{l}\text { Grade } 3-4 \\
\text { neutropenia }\end{array}$ & $88 \%$ & $92 \%$ & $50 \%$ & $42 \% *$ & $15 \%$ & $35 \%$ & $30 \%$ & $83 \%$ & $72 \% *$ \\
\hline $\begin{array}{l}\text { Grade 3-4 } \\
\text { thrombocyto- } \\
\text { penia }\end{array}$ & $38 \%$ & $44 \%$ & $7 \%$ & $1 \% *$ & $3 \%$ & $8 \%$ & $2 \%$ & $16 \%$ & $20 \%$ \\
\hline $\begin{array}{l}\text { Grade } 2 \text { or } \\
\text { higher } \\
\text { neuropathy }\end{array}$ & $6 \%$ & $7 \%$ & $17 \%$ & $6 \% *$ & $27 \%$ & $24 \%$ & $22 \%$ & $18 \%$ & $26 \% *$ \\
\hline
\end{tabular}

*A statistically significant difference $(p<0.05)$

Although the reason for differences in efficacy between trials recruiting East Asian or European/North American women is unknown, it may be explained through pharmacogenetics $[34,35]$. In addition, the interaction between bevacizumab and dose-dense regimens remains unclear and will be addressed in the ongoing ICON8B trial. Due to the variation in trial results, at present, the use of dose-dense chemotherapy is not considered standard of care management for the first-line treatment of advanced HGS cancer in Western populations.

\section{Intraperitoneal and Hyperthermic Intraperitoneal Chemotherapy}

Intraperitoneal (IP) chemotherapy delivers greater concentrations of cytotoxic agents to the peritoneal cavity compared to intravenous (IV) chemotherapy [36]. The NCCN guidelines suggest IP chemotherapy as a potential option for FIGO stage II-III EOC following optimal debulking $(<1 \mathrm{~cm} \mathrm{RD)} \mathrm{[5].} \mathrm{This}$ guidance was based on improved survival outcomes reported in the randomised phase III trial, GOG 172 [37]. ESMO guidelines recognise this trial but still regard IP chemotherapy as experimental and difficult to administer [6].

In GOG 172 , women ( $n=429$ women) that were optimally

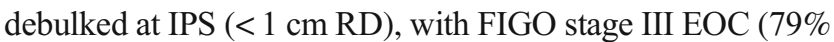
serous adenocarcinoma), were randomised to receive 6 cycles of 3-weekly IV paclitaxel $\left(135 \mathrm{mg} / \mathrm{m}^{2}\right.$ on day 1$)$ plus IV cisplatin $\left(75 \mathrm{mg} / \mathrm{m}^{2}\right.$ on day 2$)$ or 6 cycles of 3-weekly IV paclitaxel $\left(135 \mathrm{mg} / \mathrm{m}^{2}\right.$ on day 1) plus IP cisplatin $(100 \mathrm{mg} /$ $\mathrm{m}^{2}$ on day 2 ) and IP paclitaxel $\left(60 \mathrm{mg} / \mathrm{m}^{2}\right.$ on day 8$)$. GOG 172 demonstrated that patients receiving IP chemotherapy had significantly improved PFS (23.8 versus 18.3 months, HR 0.80 , $95 \%$ CI $0.64-1.00, p=0.05)$ and OS (65.6 versus 49.7 months; HR $0.75,95 \%$ CI $0.58-0.97, p=0.03$ ) [37]. Nevertheless, grade 3 and 4 adverse effects (e.g. increased pain, myelosuppression and gastrointestinal and neurological toxicity) occurred more frequently in patients treated with IP chemotherapy. In addition, the IP regimen was more frequently curtailed before completion of primary therapy, with only $42 \%$ of women receiving all 6 cycles [37]. The primary reasons for discontinuation were catheter-related e.g. infection and blockage [38]. Furthermore, post-publication discussion raised the question of the tolerability of the control arm, as only $83 \%$ of patients received all 6 cycles of IV chemotherapy, which were fewer patients than would be expected through treatment with carboplatin and paclitaxel. Aiming to address these criticisms and with the incorporation of maintenance therapies, GOG 252 was carried out.

In the randomised phase III trial, GOG 252, IP chemotherapy was delivered with concurrent IV bevacizumab [39॰]. Here, women $(n=1560)$ diagnosed with FIGO stage II-IV EOC (72.2\% HGS), who had undergone maximal cytoreduction at IPS, were randomised to receive IV weekly paclitaxel $\left(80 \mathrm{mg} / \mathrm{m}^{2}\right)$ plus one of three regimens: 3-weekly IV carboplatin (AUC6 on day 1); 3-weekly IP carboplatin (AUC6 on day 1) or 3-weekly IP cisplatin $\left(75 \mathrm{mg} / \mathrm{m}^{2}\right.$ on day 2$)$ and 3-weekly IP paclitaxel $\left(60 \mathrm{mg} / \mathrm{m}^{2}\right.$ on day 8$)$. All arms were given with the addition of 3-weekly bevacizumab ( $15 \mathrm{mg} / \mathrm{kg}$ on day 1 from cycle 2 for a maximum of 22 cycles). This trial did not report a significant difference in progressionfree survival between arms (24.9 versus 27.4 versus 
26.2 months, respectively) [39•]. The conflicting outcomes from these clinical trials have meant that IP chemotherapy has yet to be universally accepted as a routine first-line therapy. This is likely also due to the perceived complexity of delivery, reported increased toxicity, and development of newer first-line maintenance therapies [36].

Hyperthermic intraperitoneal chemotherapy (HIPEC) involves a single intra-operative administration of heated cytotoxic chemotherapy into the abdomino-pelvic cavity following surgery. The high temperature leads to increased drug penetration and tumour cell sensitivity to cytotoxic chemotherapy and induces apoptosis [40, 41]. First-line HIPEC has been investigated in two clinical trials $[42,43]$. In the randomised phase III trial, OVIHIPEC-1, 245 patients diagnosed with FIGO stage III EOC ( $89.4 \%$ HGS) were referred for NACT if IPS was not feasible or would likely have left

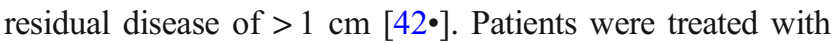
neoadjuvant 3-weekly carboplatin (AUC5/6) and 3-weekly paclitaxel $\left(175 \mathrm{mg} / \mathrm{m}^{2}\right)$ for 3 cycles and then randomised intraoperatively to receive HIPEC with IP cisplatin $\left(100 \mathrm{mg} / \mathrm{m}^{2}\right)$ or nothing. The cisplatin was administered at the end of cytoreductive surgery after the abdominal cavity had been heated to $40^{\circ} \mathrm{C}$ using heated saline. In this trial, HIPEC was associated with a significant improvement in PFS (14.2 versus 10.7 months, HR $0.66,95 \%$ CI $0.50-0.87)$ and OS (45.7 versus 33.9 months, HR $0.67,95 \%$ CI $0.48-0.94$ ) [42•]. However, the results from OVIHIPEC-1 were inconsistent with those reported in a randomised phase II undertaken in Korea [43]. In this trial, 184 women diagnosed with FIGO stage III-IV EOC were randomised intra-operatively during IPS or DPS, after optimal cytoreduction $(\mathrm{RD}<1 \mathrm{~cm})$, to receive HIPEC with IP cisplatin $\left(75 \mathrm{mg} / \mathrm{m}^{2}\right)$ or nothing. The abstract reports that there was no difference in PFS or OS between groups (PFS: 20 versus 19 months and OS: 54 versus 51 months), but peer-reviewed publication of this trial is still awaited.

The reason for the inconsistency between studies remains unclear, but the slow recruitment in both trials ( 9 years in OVIHIPEC-1; 6 years in the Korean study) suggests that HIPEC can only be delivered to a relatively small and select group of patients [44]. In addition, OVIHIPEC-1 was also criticised as the results were not stratified based on prognostic factors such as $B R C A$ status and/or histological subtype. These factors could have skewed the data in favour of the HIPEC group, which contained fewer patients with a histological diagnosis associated with a worse prognosis (i.e., mucinous, clear cell or carcinosarcoma). Moreover, the results were also very different between sites, with sites that recruited the most patients reporting worse outcomes in the HIPEC group. The OVIHIPEC-2 trial (NCT03772028) has been designed to address many of the issues that arose in previous trials and to determine if surgery with HIPEC can prolong OS with acceptable morbidity in the context of modern maintenance treatment. Patients that will be recruited are those with FIGO stage III EOC and they will be randomised to receive primary cytoreductive surgery with or without HIPEC with cisplatin.

At present, HIPEC is not widely used as standard first-line treatment and further investigation in randomised phase III trials is necessary [45]. Unfortunately, defining the position of HIPEC and IP chemotherapy in the current era is becoming harder as more effective maintenance therapies and greater understanding of BRCA/HRD start to impact first-line treatment regimens.

\section{Bevacizumab Maintenance First-Line Therapy}

Angiogenesis, the formation of new blood vessels, is a hallmark of cancer $[46,47]$. The sensitivity of EOC to vascular endothelial growth factor (VEGF) inhibition is most likely related to the fundamental role that VEGF plays in the physiology of the normal ovary [48]. Indeed, the clinical utility of VEGF inhibition, using the humanised monoclonal antiVEGF antibody bevacizumab, within first-line treatment of EOC, has been demonstrated in two randomised phase III trials $[49,50]$.

In ICON7, 1528 women diagnosed with FIGO stage IIBIV EOC (69\% serous adenocarcinoma) were randomised to receive 3-weekly carboplatin (AUC5/6) plus 3-weekly paclitaxel $\left(175 \mathrm{mg} / \mathrm{m}^{2}\right)$ with or without 3-weekly bevacizumab $(7.5 \mathrm{mg} / \mathrm{kg})$. Bevacizumab was administered concurrently with chemotherapy and continued thereafter for a maximum of 18 cycles in total. The addition of bevacizumab significantly improved median PFS (19.0 versus 17.3 months, HR 0.81, 95\% CI 0.70-0.94) [49], but an improvement in median OS was only demonstrated in women considered at "high-risk" of developing relapsed disease (39.7 versus 30.2 months, HR $0.78,95 \%$ CI 0.63-0.97) [51]. High-risk disease included FIGO stage III with $>1 \mathrm{~cm}$ of RD following cytoreductive surgery, FIGO stage IV disease and/or inoperable disease [51].

In GOG 218, 1837 patients diagnosed with incompletely resected FIGO stage III or FIGO stage IV EOC (83.6\% serous adenocarcinoma) were randomised to receive 3-weekly carboplatin (AUC6) plus 3-weekly paclitaxel $\left(175 \mathrm{mg} / \mathrm{m}^{2}\right)$ with or without 3 -weekly bevacizumab $(15 \mathrm{mg} / \mathrm{kg})$. Bevacizumab was administered concurrently with chemotherapy only (cycles 2-6) or alongside chemotherapy and as maintenance (cycle 2-22) for a maximum of 21 cycles in total. The group of patients that continued bevacizumab as maintenance achieved a significantly improved PFS compared to those that had chemotherapy alone (14.1 versus 10.3 months, HR 0.717 , 95\% CI 0.0625-0.824) [50]. In keeping with ICON7, GOG 218 also demonstrated that patients with FIGO stage IV disease achieved significantly longer OS (42.8 versus 
32.6 months, HR $0.75,95 \%$ CI $0.59-0.95$ ) with bevacizumab $[52 \bullet \bullet]$.

Following the results of ICON7 and GOG 218, bevacizumab was recommended for use in the first-line management of patients with advanced stage EOC, to be used alongside chemotherapy and continued for 15 (12 in the UK) months as maintenance therapy $[5,6]$. It remains unclear if additional cycles of bevacizumab can extend PFS further, and so the results of the BOOST trial (NCT01462890) are eagerly awaited; comparing 15 versus 30 cycle in the firstline setting.

Other anti-angiogenic agents, including nintedanib [53] and pazopanib [54] also showed improved PFS in the firstline setting as maintenance therapies, although these orally administered small molecule tyrosine kinase inhibitors demonstrated an increased incidence of diarrhoea and haematological toxicities.

There has been a global search for biomarkers that could be used to optimise the use of VEGF inhibitors. We have shown that a reduction and subsequent increase in plasma Tie2, in patients with ovarian or colorectal cancer treated with bevacizumab, reflect vascular response and then vascular progression, respectively $[55,56]$. Taken in conjunction with similar pharmacodynamic changes in plasma Tie2, induced by cediranib in patients diagnosed with glioma [57], these findings together suggest that plasma Tie2 is the first tumour vascular response biomarker for VEGF inhibitors [58]. Further prospective validation of Tie 2 utility is underway in the VALTIVE-1 study.

\section{Poly(ADP-Ribose) Polymerase Inhibitors}

Recently, poly(ADP-ribose) polymerase (PARP) inhibitors have changed the outlook for some women with FIGO stage III/IV HGS carcinoma. Small molecule inhibitors of PARP1 and PARP2 act in BRCA-mutant and Homologous recombination-deficient (HRD) tumours, probably through the mechanistic framework of synthetic lethality, although there are several theories for the exact mechanism of action [59]. Approximately $20 \%$ of HGS tumours have a germline or somatic BRCA1/2 mutation and in total up to $50 \%$ are HRD $[60,61]$; both mechanisms playing important roles in DNA repair and error-free repair of double-strand breaks (DSBs), respectively. In HRD tumour cells, alternative "error-prone" DSB repair pathways (e.g. non-homologous end joining [NHEJ]) are more heavily relied upon, thereby leading to genomic instability [62]. One theory is that PARP inhibitors can exploit this unique molecular feature of HGS carcinoma by inhibiting DNA single-strand break (SSB) repair [63, 64]. Indeed, unrepaired SSBs may form lethal DSB during the G2/S-phase of the cell cycle. Subsequently, HRD tumours that are unable to repair DSBs are more likely to die after exposure to PARP inhibitors. PARP inhibitors prevent repair of SSBs by inhibiting catalytic formation of polymers of ADP-ribose forming and trapping PARP1 on DNA $[65,66]$. The NHEJ pathway also appears to play a key role in the way PARP inhibitors work in HRD cells and studies have shown cells with already defective NHEJ may in fact be resistant PARP inhibitors [67, 68].

A number of randomised phase III trials have recently reported the efficacy of PARP inhibitors as first-line maintenance monotherapy [69-71] (Table 3). SOLO-1 reported a $70 \%$ reduction in the risk of progression or death in patients with FIGO stage III/IV BRCA-mutant (germline or somatic) platinum-sensitive HGS or high-grade endometrioid carcinoma following 24 months of olaparib (300 $\mathrm{mg}$ twice daily) compared to placebo (HR 0.30, 95\% CI 0.23-0.41) [69・•] (Table 3). In the PRIMA trial, 733 patients with FIGO stage III-IV HGS carcinoma were randomised following a complete/partial response to cytoreductive surgery plus platinum-based chemotherapy to receive either niraparib (300 mg once daily, 28-day cycles) or placebo for a maximum of 36 months [70••]. The trial reported an improvement in PFS in all patients with niraparib compared to placebo (13.8 versus 8.2 months, HR $0.62,95 \%$ CI $0.05-0.76$ ). The greatest benefits in PFS were demonstrated in BRCA-mutant and/or HRD tumours (Table 3).

In the VELIA trial, 1140 women with FIGO stage III-IV HGSC were randomised prior to receiving first-line multi-modality therapy to one of 3 arms: (A) chemotherapy with concurrent and maintenance veliparib (150 mg twice-daily) or (B) chemotherapy with concurrent veliparib and placebo maintenance therapy or (C) placebo throughout chemotherapy and as maintenance $[71 \bullet \bullet$. For patients randomised to take veliparib with and following chemotherapy, a PFS advantage was demonstrated, again with the greatest benefits reported in patients with BRCA-mutant and HRD tumours (Table 3). There was no significant difference in PFS between the group that took veliparib with chemotherapy only in comparison with the placebo group. Interestingly, unlike olaparib or niraparib, veliparib was administered concurrently with platinum therapy, whereas previous trials had shown that combining PARP inhibitors and platinum caused intolerable myelotoxicity [72].

The most common adverse effects of PARP inhibitors reported in trials were myelosuppression, nausea and fatigue (Table 4). The olaparib trial reported fewer incidences of grade 3 or above anaemia or neutropenia than niraparib and veliparib. More rare, but clinically significant, adverse effects such as pneumonitis, myelodysplastic syndrome and acute myeloid leukaemia were reported infrequently in the trials but more commonly with olaparib (Table 4) [69-71].

In PRIMA and VELIA, HRD tumours were identified through the myChoice ${ }^{\circledR}$ companion diagnostic (CDx) test (Myriad Genetics, Inc., Salt Lake City, UT, USA). This assay determines an HRD "score" using three algorithms calculating 
Table 3 PFS outcomes in PARP inhibitor trials based on genetic stratification [69-71]

\begin{tabular}{|c|c|c|c|c|c|c|c|c|}
\hline \multirow[t]{2}{*}{ PFS (months) } & \multicolumn{2}{|l|}{ SOLO1 } & \multicolumn{2}{|l|}{ PRIMA } & \multicolumn{2}{|l|}{ VELIA } & \multicolumn{2}{|l|}{ PAOLA-1 } \\
\hline & $\begin{array}{l}\text { Control } \\
\text { arm } \\
\text { Placebo }\end{array}$ & $\begin{array}{l}\text { Experimental } \\
\text { arm } \\
\text { Oral olaparib } \\
300 \text { mg BD } \\
\text { maintenance } \\
\text { after } \\
\text { chemotherapy }\end{array}$ & $\begin{array}{l}\text { Control } \\
\text { arm } \\
\text { Placebo }\end{array}$ & $\begin{array}{l}\text { Experimental } \\
\text { arm } \\
\text { Oral niraparib } \\
300 \text { mg OD } \\
\text { maintenance } \\
\text { after } \\
\text { chemotherapy }\end{array}$ & $\begin{array}{l}\text { Control } \\
\text { arm } \\
\text { Placebo }\end{array}$ & $\begin{array}{l}\text { Experimental arm } \\
\text { Oral veliparib } \\
150 \text { mg BD } \\
\text { throughout } \\
\text { chemotherapy and } \\
\text { continued as } \\
\text { maintenance }\end{array}$ & $\begin{array}{l}\text { Control arm } \\
\text { Placebo + } \\
\text { bevacizumab } \\
15 \mathrm{mg} / \mathrm{kg}\end{array}$ & $\begin{array}{l}\text { Experimental arm } \\
\text { Oral olaparib } 300 \mathrm{mg} \\
\text { BD maintenance } \\
\text { after } \\
\text { chemotherapy + } \\
\text { bevacizumab } \\
15 \mathrm{mg} / \mathrm{kg}\end{array}$ \\
\hline $\begin{array}{l}\text { Intention-to-treat } \\
\text { population }\end{array}$ & N/A & N/A & 8.2 & $\begin{array}{l}13.8 \\
\text { (HR } 0.62,95 \% \\
\quad \text { CI } \\
0.50-0.76)\end{array}$ & 17.3 & $\begin{array}{l}23.5 \\
(\mathrm{HR} 0.68,95 \% \mathrm{CI} \\
\quad 0.56-0.83)\end{array}$ & 16.6 & $\begin{array}{l}22.1 \\
(\mathrm{HR} 0.59,95 \% \mathrm{CI} \\
\quad 0.49-0.72)\end{array}$ \\
\hline $\begin{array}{l}\text { All HRD positive } \\
\text { (includes BRCA1/2 } \\
\text { mutation) }\end{array}$ & N/A & N/A & 10.9 & $\begin{array}{l}22.1 \\
\text { (HR } 0.40,95 \% \\
\quad \text { CI } \\
0.27-0.62 \text { ) }\end{array}$ & 20.5 & $\begin{array}{l}31.9 \\
(\mathrm{HR} 0.57,95 \% \mathrm{CI} \\
\quad 0.43-0.76)\end{array}$ & 17.7 & $\begin{array}{l}37.2 \\
(\mathrm{HR} 0.33,95 \% \mathrm{CI} \\
\quad 0.25-0.45)\end{array}$ \\
\hline $\begin{array}{l}\text { HRD } \\
\text { positive/BRCA-wildt- } \\
\text { ype }\end{array}$ & N/A & N/A & 8.2 & $\begin{array}{l}19.6 \\
\text { (HR } 0.50,95 \% \\
\quad \text { CI } \\
0.31-0.83)\end{array}$ & N/A & N/A & 16.6 & $\begin{array}{l}28.1 \\
(\mathrm{HR} 0.43,95 \% \mathrm{CI} \\
\quad 0.28-0.66)\end{array}$ \\
\hline$B R C A 1 / 2$ mutation & 13.8 & $\begin{array}{l}49.9 \\
\text { (HR 0.30, } \\
95 \% \text { CI } \\
0.23-0.41)\end{array}$ & N/A & N/A & 22.0 & $\begin{array}{l}34.7 \\
(\mathrm{HR} 0.44,95 \% \mathrm{CI} \\
\quad 0.28-0.68)\end{array}$ & 21.7 & $\begin{array}{l}37.2 \\
\text { (HR 0.3, } 1 \\
95 \% \text { CI } 0.20-0.47)\end{array}$ \\
\hline HR-competent & N/A & N/A & N/A & N/A & N/A & N/A & 16.2 & $\begin{array}{l}16.6 \\
\text { (HR } 1.00,95 \% \text { CI } \\
\quad 0.75-1.35)\end{array}$ \\
\hline
\end{tabular}

genetic aberrations in single nucleotide polymorphisms (SNPs). These algorithms assess genetic characteristics of tumour DNA, including loss of heterozygosity $(\mathrm{LOH})$, telomeric allelic imbalance (TAI) and large-scale transitions (LST), all surrogate markers of genomic instability [73-75]. The assay provides an HRD "score" that is calculated based on the accumulative score of each algorithm (LOH, TAI and
LST). A tumour is considered HRD according to a set score e.g. in PRIMA HRD tumours had a HRD score $\geq 42$, whereas in VELIA, the threshold was set at 33 [70, 71]. In both trials, women with HRD tumours who received the PARP inhibitor had significantly longer PFS compared to those who received placebo. The difference in the HRD score may impact upon the choice of PARP inhibitor used in front-line therapy.

Table 4 Common and serious adverse events reported in PARP inhibitor trials [69-71]

\begin{tabular}{|c|c|c|c|c|c|c|}
\hline \multirow[b]{2}{*}{ Event } & \multicolumn{2}{|c|}{ SOLO-1 trial—olaparib group } & \multicolumn{2}{|c|}{ PRIMA trial—niraparib group } & \multicolumn{2}{|c|}{ VELIA trial—veliparib throughout group } \\
\hline & $\begin{array}{l}\text { Any grade } \\
\text { ( } \% \text { of patients) }\end{array}$ & $\begin{array}{l}\text { Grade } 3 \text { or } 4 \\
\text { (\% of patients) }\end{array}$ & $\begin{array}{l}\text { Any grade } \\
\text { ( } \% \text { of patients) }\end{array}$ & $\begin{array}{l}\text { Grade } 3 \text { or } 4 \\
\text { (\% of patients) }\end{array}$ & $\begin{array}{l}\text { Any grade } \\
\text { ( } \% \text { of patients) }\end{array}$ & $\begin{array}{l}\text { Grade } 3 \text { or } 4 \\
\text { (\% of patients) }\end{array}$ \\
\hline Anaemia & 39 & 22 & 63 & 31 & 64 & 38 \\
\hline Neutropenia & 23 & 9 & 26 & 12 & 75 & 58 \\
\hline Thrombocytopenia & 11 & 1 & 46 & 29 & 58 & 28 \\
\hline Nausea & 77 & 1 & 57 & 1 & 80 & 8 \\
\hline Fatigue & 63 & 4 & 35 & 2 & 69 & 8 \\
\hline Pneumonitis & 2 & $\mathrm{~N} / \mathrm{A}$ & 0 & N/A & 0 & N/A \\
\hline Acute myeloid leukaemia & 1 & N/A & 0 & N/A & 0.3 & N/A \\
\hline Myelodysplatic syndrome & 0 & N/A & 0.2 & N/A & $0^{*}$ & N/A \\
\hline
\end{tabular}

*There was an incidence of myelodysplastic syndrome in 1 patient $(0.2 \%)$ in veliparib combination only group in this trial [71] 
Table 5 Ongoing first-line phase III clinical trials involving immune checkpoint inhibitors with combination regimens

\begin{tabular}{|c|c|c|c|c|c|}
\hline Trial name & GOG3015/ENGOT OV39 & $\begin{array}{l}\text { FIRST trial/ } \\
\text { ENGOT Ov-44 }\end{array}$ & $\begin{array}{l}\text { DUO-O/ } \\
\text { ENGOT Ov-46 }\end{array}$ & $\begin{array}{l}\text { ENGOT Ov-43/ } \\
\text { MK7339-001 }\end{array}$ & ATHENA \\
\hline Trial identifier & NCT03038100 & NCT03602859 & NCT03737643 & NCT03740165 & NCT03522246 \\
\hline Histology & Epithelial & Epithelial & Epithelial & Epithelial & Epithelial \\
\hline FIGO stage & III-IV & III-IV & III-IV & III-IV & III-IV \\
\hline ECOG PS & $0-2$ & $0-1$ & $0-2$ & $0-1$ & $0-2$ \\
\hline Investigational drugs & Atezolizumab & $\begin{array}{l}\text { Dorstarlimab } \\
\text { Niraparib }\end{array}$ & $\begin{array}{l}\text { Durvalumab } \\
\text { Olaparib }\end{array}$ & $\begin{array}{l}\text { Pembrolizumab } \\
\text { Olaparib }\end{array}$ & $\begin{array}{l}\text { Nivolumab } \\
\text { Rucaparib }\end{array}$ \\
\hline $\begin{array}{l}\text { Control } \\
\text { arm-chemotherapy } \\
\text { phase }\end{array}$ & $\begin{array}{l}\text { IV paclitaxel } \\
+ \text { IV carboplatin } \\
\text { + IV bevacizumab } \\
\text { + IV atezolizumab placebo }\end{array}$ & $\begin{array}{l}\text { Arm 1: } \\
\text { Standard of care } \\
\text { chemotherapy } \\
+ \text { IV dorstarlimab } \\
\text { placebo }\end{array}$ & $\begin{array}{l}\text { Arm 1: } \\
\text { IV paclitaxel } \\
+ \text { IV } \\
\quad \text { carboplatin } \\
+ \text { IV } \\
\quad \text { bevacizumab } \\
+ \text { IV } \\
\quad \text { durvalumab } \\
\text { placebo }\end{array}$ & $\begin{array}{l}\text { Arm 3: } \\
\text { IV paclitaxel } \\
+ \text { IV carboplatin } \\
\pm \text { IV bevacizumab } \\
+ \text { IV pembrolizumab } \\
\quad \text { placebo }\end{array}$ & $\mathrm{N} / \mathrm{A}$ \\
\hline $\begin{array}{l}\text { Control } \\
\text { arm-maintenance } \\
\text { phase }\end{array}$ & $\begin{array}{l}\text { IV bevacizumab } \\
+ \text { IV atezolizumab placebo }\end{array}$ & $\begin{array}{l}\text { Arm 1: } \\
\text { IV dorstarlimab } \\
\quad \text { placebo } \\
+ \text { PO niraparib } \\
\quad \text { placebo }\end{array}$ & $\begin{array}{l}\text { Arm 1: } \\
\text { IV } \\
\quad \text { bevacizumab } \\
+ \text { IV } \\
\quad \text { durvalumab } \\
\text { placebo } \\
+ \text { PO olaparib } \\
\text { placebo }\end{array}$ & $\begin{array}{l}\text { Arm 3: } \\
\pm \text { IV bevacizumab } \\
+ \text { IV pembrolizumab } \\
\quad \text { placebo } \\
+ \text { PO olaparib placebo }\end{array}$ & $\begin{array}{l}\text { Arm D: } \\
\text { IV nivolumab placebo } \\
\quad+\text { PO rucaparib } \\
\text { placebo }\end{array}$ \\
\hline $\begin{array}{l}\text { Experimental arm } \\
\text { (1)-chemotherapy } \\
\text { phase }\end{array}$ & $\begin{array}{l}\text { IV paclitaxel } \\
+ \text { IV carboplatin } \\
+ \text { IV bevacizumab } \\
+ \text { IV atezolizumab (1200 mg, } \\
\text { three-weekly) }\end{array}$ & $\begin{array}{l}\text { Arm 2: } \\
\text { Standard of care } \\
\text { chemotherapy } \\
+ \text { IV dorstarlimab } \\
\text { placebo }\end{array}$ & $\begin{array}{l}\text { Arm 2: } \\
\text { IV paclitaxel } \\
+ \text { IV } \\
\quad \text { carboplatin } \\
+ \text { IV } \\
\quad \text { bevacizumab } \\
+ \text { IV } \\
\quad \text { durvalumab }\end{array}$ & $\begin{array}{l}\text { Arm 1: } \\
\text { IV paclitaxel } \\
+ \text { IV carboplatin } \\
\pm \text { IV bevacizumab } \\
+ \text { IV pembrolizumab } \\
\quad \text { (200 mg, three } \\
\quad \text { weekly) }\end{array}$ & N/A \\
\hline $\begin{array}{l}\text { Experimental arm } \\
\text { (1)-maintenance } \\
\text { phase }\end{array}$ & $\begin{array}{l}\text { IV bevacizumab } \\
+ \text { IV atezolizumab (1200 mg, } \\
\text { three-weekly) }\end{array}$ & $\begin{array}{l}\text { Arm 2: } \\
\text { IV dorstarlimab } \\
\quad \text { placebo } \\
+ \text { PO niraparib }\end{array}$ & $\begin{array}{l}\text { Arm } 2 \text { : } \\
\text { IV } \\
\quad \text { bevacizumab } \\
+ \text { IV } \\
\quad \text { durvalumab } \\
+ \text { PO olaparib } \\
\quad \text { placebo }\end{array}$ & $\begin{array}{l}\text { Arm 1: } \\
\pm \text { IV bevacizumab } \\
+ \text { IV pembrolizumab } \\
\text { ( } 200 \mathrm{mg}, \\
\text { three-weekly) } \\
+ \text { PO olaparib } \\
\quad \text { (300 mg, } \\
\text { twice-daily) }\end{array}$ & $\begin{array}{l}\text { Arm A: } \\
\text { IV nivolumab } \\
\quad \text { (four-weekly) } \\
+ \text { PO rucaparib } \\
\quad \text { (twice-daily) }\end{array}$ \\
\hline $\begin{array}{l}\text { Experimental arm } \\
\text { (2)-chemotherapy } \\
\text { phase }\end{array}$ & $\mathrm{N} / \mathrm{A}$ & $\begin{array}{l}\text { Arm 3: } \\
\text { Standard of care } \\
\quad \text { chemotherapy } \\
+ \text { IV dorstarlimab }\end{array}$ & $\begin{array}{l}\text { Arm } 3 / \text { patients } \\
\text { with } \\
\text { tBRCAm: } \\
\text { IV paclitaxel } \\
+ \text { IV } \\
\text { carboplatin } \\
\pm \text { IV } \\
\text { cevacizumab } \\
+ \text { IV } \\
\text { durvalumab }\end{array}$ & $\begin{array}{l}\text { Arm 2: } \\
\text { IV paclitaxel } \\
+ \text { IV carboplatin } \\
\pm \text { IV bevacizumab } \\
+ \text { IV pembrolizumab }\end{array}$ & N/A \\
\hline $\begin{array}{l}\text { Experimental Arm } \\
\text { (2)-maintenance } \\
\text { phase }\end{array}$ & $\mathrm{N} / \mathrm{A}$ & $\begin{array}{l}\text { Arm 3: } \\
\text { IV } \\
\quad \text { dorstarlimab + } \\
\quad \text { PO niraparib }\end{array}$ & $\begin{array}{l}\text { Arm 3/patients } \\
\text { with } \\
\text { tBRCAm: } \\
\pm \text { IV } \\
\text { bevacizumab } \\
+ \text { IV } \\
\text { durvalumab } \\
+ \text { PO olaparib }\end{array}$ & $\begin{array}{l}\text { Arm 2: } \\
\pm \text { IV bevacizumab } \\
+ \text { IV pembrolizumab } \\
\quad(200 \mathrm{mg}, \\
\text { three-weekly) } \\
+ \text { PO olaparib placebo }\end{array}$ & $\begin{array}{l}\text { Arm B: } \\
\text { IV nivolumab placebo } \\
+ \text { PO rucaparib } \\
\quad \text { (twice-daily) }\end{array}$ \\
\hline & N/A & N/A & N/A & N/A & Arm C: \\
\hline
\end{tabular}


Table 5 (continued)

\begin{tabular}{|c|c|c|c|c|c|}
\hline Trial name & GOG3015/ENGOT OV39 & $\begin{array}{l}\text { FIRST trial/ } \\
\text { ENGOT Ov-44 }\end{array}$ & $\begin{array}{l}\text { DUO-O/ } \\
\text { ENGOT Ov-46 }\end{array}$ & $\begin{array}{l}\text { ENGOT Ov-43/ } \\
\text { MK7339-001 }\end{array}$ & ATHENA \\
\hline $\begin{array}{l}\text { Experimental arm } \\
\text { (3)-maintenance } \\
\text { phase }\end{array}$ & & & & & $\begin{array}{l}\text { IV nivolumab } \\
\quad \text { (four-weekly) } \\
+ \text { PO rucaparib placebo }\end{array}$ \\
\hline Primary outcome & $\begin{array}{l}\text { PFS in intention to treat (ITT) } \\
\text { population } \\
\text { PFS in programmed cell death-ligand } \\
1 \text { (PD-L1)-positive subpopulation } \\
\text { OS in ITT population } \\
\text { OS in PD-L1-positive population }\end{array}$ & PFS & $\begin{array}{l}\text { PFS-in } \\
\text { non-tBRCA- } \\
\text { m patients }\end{array}$ & $\begin{array}{l}\text { PFS } \\
\text { OS }\end{array}$ & PFS \\
\hline
\end{tabular}

Overall, the outcomes of these trials show that patients with known $B R C A 1 / 2$ mutations benefit from PARP inhibitors as maintenance monotherapy after a response to first-line platinum-based chemotherapy. In addition, those patients with HRD tumours benefit from niraparib or veliparib, and have similar risks of adverse effects (Table 4). Although further analysis of OS is awaited in all three trials, surrogate markers of OS including time-to-first subsequent therapy (TFST), progression-free survival 2 (PFS2) and time-to-second subsequent therapy (TSST) suggest early indications of long-term survival benefit [69••]. It is becoming increasingly important to test all patients for germline and somatic $B R C A 1 / 2$ mutations at diagnosis to help guide maintenance options, and recent approval in the USA of the Myriad myChoice ${ }^{\circledR} \mathrm{CDx}$ represents an additional biomarker for assessment in $B R C A$ wildtype patients.

\section{Immunotherapy}

Immune checkpoint blockade with anti-CTLA-4 and/or antiPD-1/PD-L1 inhibitors is not routinely used in the management of HGS carcinoma at present. Early phase trials have reported relatively disappointing response rates of between 10 and 20\% [76-78]. Indeed, the randomised first-line phase III trial, JAVELIN Ovarian 100 trial (NCT02718417) was prematurely discontinued due to insufficient activity. This trial had been recruiting patients with stage III-IV EOC that were due to start platinum-based chemotherapy. Patients were to be randomised to receive 3-weekly avelumab (an anti-PD-L1 antibody) during chemotherapy or during chemotherapy and as maintenance therapy or chemotherapy alone. As a result of the interim results of JAVELIN Ovarian 100, another randomised phase III trial, JAVELIN Ovarian PARP 100 trial (NCT03642132), investigating avelumab plus the PARP inhibitor, talazoparib, was also prematurely discontinued [79].

BRCA-mutated HGS carcinoma and TP53-mutated EOC often contain increased number of tumour-infiltrating lymphocytes and express PD-1/PD-L1 [80, 81], suggesting that immune checkpoint inhibitors should be effective. However, copy number variation is more common than neoantigen formation in HGS and hence checkpoint inhibitors used alone have not yielded meaningful activity. In an attempt to overcome this problem, multiple trials have been initiated that aim to boost the immune response through concurrent administration of immune oncology agents with PARP and/or VEGF inhibitors (Table 5).

\section{Combination First-Line Maintenance Treatment}

Recent clinical trials in EOC have started to evaluate combinations of VEGF and PARP inhibitors. An initial randomised phase II treatment trial described increased PFS and OS in patients with recurrent platinum-sensitive EOC that were treated with a combination of cediranib (30 mg, once daily) plus olaparib (capsules; $200 \mathrm{mg}$, twice-daily) compared to olaparib alone. Importantly, this benefit was more evident in patients with no $B R C A 1 / 2$ mutation $[82,83]$. Mechanistic studies have shown that the increased activity of combination therapy is related to hypoxia-driven reduction in the proteins involved in HR repair, which then resulted in reduced BRCA expression and function, sensitising $B R C A 1 / 2$ wild-type cells to PARP inhibitors [84].

The only trial to assess the combination of PARP and VEGF inhibition in first-line management of EOC is PAOLA-1 [85••]. In this randomised phase III trial, 806 women with FIGO stage III-IV high-grade serous or endometrioid ovarian cancers $(95.8 \%$ HGS) had responded to first-line platinum-taxane chemotherapy, and bevacizumab were randomised to receive either ongoing 3-weekly bevacizumab $(15 \mathrm{mg} / \mathrm{kg})$ as maintenance for a maximum of 15 months total with olaparib (300 mg, twice-daily) for up to 24 months, or bevacizumab with placebo. Tumour samples were analysed for BRCA mutation and HRD testing prior to randomisation, with an HRD score of $\geq 42$ indicating a positive result. A PFS benefit was demonstrated in the combination arm 
(investigator-assessed PFS: 22.1 versus 16.6 months, HR $0.59,95 \%$ CI 0.49-0.72), with the most profound PFS advantage being reported in patients with BRCA1/2 mutations (Table 3) [85••]. The main criticism of PAOLA-1 was that there was no single agent olaparib maintenance monotherapy arm included, which made it difficult to determine if the PFS advantage in patients with HRD tumours was due to synergy between bevacizumab-olaparib or olaparib alone.

Results from phase III trials combining immune checkpoint inhibitors with VEGF or PARP inhibitors in first-line management of EOC are eagerly awaited (Table 5). The rationale for use of PARP inhibitors is the increased DNA damage in cells, which might increase neoantigen formation and hence the effects of immunotherapy [86]. In contrast, VEGF inhibitors act by converting an immunosuppressive tumour microenvironment (TME) to an immunosupportive one, potentially increasing sensitivity to immunotherapy $[87,88]$. If the results of combinational agents prove effective, it will be critical to develop biomarkers that will optimise treatment of the right patients so that cost-effectiveness is delivered.

\section{Conclusion}

The first-line treatment of HGS carcinoma now builds on the well-established backbone of surgery and paclitaxel/platinumbased chemotherapy. Surgery can be carried out upon diagnosis or after NACT. The role of IP chemotherapy and HIPEC remains undefined.

Maintenance monotherapies with bevacizumab and PARP inhibitors have demonstrated progression-free survival benefits in certain clinically and molecularly defined subgroups. Key questions remain over the benefits of combination regimens and whether molecularly targeted biomarkers can optimise patient stratification. Nevertheless, $70 \%$ of patients are likely to develop recurrent disease and require further treatment. Bevacizumab has proven effective in the re-use setting [89] but trials on the re-use of PARP inhibitors are currently ongoing (NCT03136987). Therefore, based on current evidence, it is vital to decide which drugs should be used upfront and which should be saved for use in relapse.

Recent phase III trials highlight the future need for randomised trials on the re-use of maintenance therapies, the upfront testing of BRCA and HRD status and the ongoing development of biomarkers for use of VEGFi.

\section{Compliance with Ethical Standards}

Conflict of Interest Andrew R. Clamp has received research funding from AstraZeneca, has received compensation from AstraZeneca and Tesaro for service as a consultant and has received non-financial support from AstraZeneca, Clovis Oncology, and Tesaro.

Reem D. Mahmood, Robert D. Morgan, Richard J. Edmondson and Gordon C. Jayson declare that they have no conflict of interest.
Human and Animal Rights and Informed Consent This article does not contain any studies with human or animal subjects performed by any of the authors.

Open Access This article is licensed under a Creative Commons Attribution 4.0 International License, which permits use, sharing, adaptation, distribution and reproduction in any medium or format, as long as you give appropriate credit to the original author(s) and the source, provide a link to the Creative Commons licence, and indicate if changes were made. The images or other third party material in this article are included in the article's Creative Commons licence, unless indicated otherwise in a credit line to the material. If material is not included in the article's Creative Commons licence and your intended use is not permitted by statutory regulation or exceeds the permitted use, you will need to obtain permission directly from the copyright holder. To view a copy of this licence, visit http://creativecommons.org/licenses/by/4.0/.

\section{References}

Papers of particular interest, published recently, have been highlighted as:

- Of importance

-• Of major importance

1. Bray F, Ferlay J, Soerjomataram I, Siegel RL, Torre LA, Jemal A. Global cancer statistics 2018: GLOBOCAN estimates of incidence and mortality worldwide for 36 cancers in 185 countries. CA Cancer J Clin. 2018;68(6):394-424. https://doi.org/10.3322/caac. 21492.

2. Mutch DG, Prat J. 2014 FIGO staging for ovarian, fallopian tube and peritoneal cancer. Gynecol Oncol. 2014;133(3):401-4.

3. Reid BM, Permuth JB, Sellers TA. Epidemiology of ovarian cancer: a review. Cancer Biol Med. 2017;14:9-32.

4. Kurman RJ. Origin and molecular pathogenesis of ovarian highgrade serous carcinoma. Ann Oncol. 2013;24:x16-21.

5. National Comprehensive Cancer Network. NCCN clinical practice guidelines in oncology: ovarian cancer version. 2019;

6. Ledermann JA, Raja FA, Fotopoulou C, Gonzalez-Martin A, Colombo N, Sessa C. Newly diagnosed and relapsed epithelial ovarian carcinoma: ESMO clinical practice guidelines for diagnosis, treatment and follow-up. Ann Oncol. 2013;24(SUPPL.6).

7. Jayson GC, Kohn EC, Kitchener HC, Ledermann JA. Ovarian cancer. Lancet. 2014;384(9951):1376-88.

8. UK CR. Ovarian cancer survival statistics [Internet]. Available from: https://www.cancerresearchuk.org/health-professional/ cancer-statistics/statistics-by-cancer-type/ovarian-cancer/survival. Accessed 5 May 2020

9. du Bois A, Reuss A, Pujade-Lauraine E, Harter P, Ray-Coquard I, Pfisterer J. Role of surgical outcome as prognostic factor in advanced epithelial ovarian cancer: a combined exploratory analysis of 3 prospectively randomized phase 3 multicenter trials. Cancer. 2009;115(6):1234-44. https://doi.org/10.1002/cncr.24149.

10. Bristow RE, Montz FJ, Lagasse LD, Leuchter RS, Karlan BY. Survival impact of surgical cytoreduction in stage IV epithelial ovarian cancer. Gynecol Oncol. 1999;72(3):278-87.

11. Querleu D, Planchamp F, Chiva L, Fotopoulou C, Barton D, Cibula D, et al. European Society of Gynaecological Oncology (ESGO) Guidelines for Ovarian Cancer Surgery. Int J Gynecol Cancer. 2017;27(7):1534 42. https://doi.org/10.1097/IGC.0000000000001041.

12. Vergote I, Tropé CG, Amant F, Kristensen GB, Ehlen T, Johnson N, et al. Neoadjuvant chemotherapy or primary surgery in stage IIIC or 
IV ovarian cancer. N Engl J Med. 2010;363(10):943-53. https://doi. org/10.1056/NEJMoa0908806.

13. Kehoe S, Hook J, Nankivell M, Jayson GC, Kitchener H, Lopes T, et al. Primary chemotherapy versus primary surgery for newly diagnosed advanced ovarian cancer (CHORUS): an open-label, randomised, controlled, non-inferiority trial. Lancet. 2015;386(9990):249-57.

14. Vergote I, Coens C, Nankivell M, Kristensen GB, MKB P, Ehlen T, et al. Neoadjuvant chemotherapy versus debulking surgery in advanced tubo-ovarian cancers: pooled analysis of individual patient data from the EORTC 55971 and CHORUS trials. Lancet Oncol. 2018;19(12):1680-7. Pooled analysis of two randomised phase III trials, EORTC 55971 and CHORUS, looking into immediate primary surgery compared to delayed primary surgery in advanced (FIGO stage IIIA-IV) epithelial ovarian cancer. The pooled analysis showed prolonged OS in patients with stage IV disease being treated with neo-adjuvant chemotherapy and delayed primary surgery.

15. Reuss A, du Bois A, Harter P, Fotopoulou C, Sehouli J, Aletti G, et al. TRUST: trial of radical upfront surgical therapy in advanced ovarian cancer (ENGOT ov33/AGO-OVAR OP7). Int J Gynecol Cancer. 2019;29(8):1327-31. https://doi.org/10.1136/ijgc-2019000682.

16. Vergote IB, Van Nieuwenhuysen E, Vanderstichele A. How to select neoadjuvant chemotherapy or primary debulking surgery in patients with stage IIIC or IV ovarian carcinoma. J Clin Oncol. 2016;34(32):3827-8. https://doi.org/10.1200/JCO.2016.69.7458.

17. Wright AA, Bohlke K, Armstrong DK, Bookman MA, Cliby WA, Coleman RL, et al. Neoadjuvant chemotherapy for newly diagnosed, advanced ovarian cancer: Society of Gynecologic Oncology and American Society of Clinical Oncology Clinical Practice Guideline. J Clin Oncol. 2016;34(28):3460-73. https:// doi.org/10.1200/JCO.2016.68.6907.

18. Chan JK, Urban R, Hu JM, Shin JY, Husain A, Teng NN, et al. The potential therapeutic role of lymph node resection in epithelial ovarian cancer: a study of 13918 patients. Br J Cancer. 2007;96(12): $1817-22$

19. du Bois A, Reuss A, Harter P, Pujade-Lauraine E, Ray-Coquard I, Pfisterer J. Potential role of lymphadenectomy in advanced ovarian cancer: a combined exploratory analysis of three prospectively randomised phase III multicenter trials. J Clin Oncol. 2010;28(10):1733-9. https://doi.org/10.1200/JCO.2009.25.3617.

20. Panici PB, Maggioni A, Hacker N, Landoni F, Ackermann S, Campagnutta E, et al. Systematic aortic and pelvic lymphadenectomy versus resection of bulky nodes only in optimally debulked advanced ovarian cancer: a randomized clinical trial. JNCI J Natl Cancer Inst. 2005;97(8):560-6.

21. Harter P, Sehouli J, Lorusso D, Reuss A, Vergote I, Marth C, et al. LION: Lymphadenectomy in ovarian neoplasms - a prospective randomized AGO study group led gynecologic cancer intergroup trial. J Clin Oncol. 2017;35(15_suppl):5500. https://doi.org/10. 1200/JCO.2017.35.15 suppl.5500 A randomised phase III trial investigating the $\mathrm{OS}^{-}$benefit in complete lymphadenectomy during surgery for patients with FIGO stage IIB-IV epithelial ovarian cancer. This trial showed no OS benefit with complete lymphadenectomy compared to removal of only clinically suspicious lymph nodes, but increased post-operative morbidity and mortality.

22. National Institute of Heath and Care Excellence. Guidance on the use of paclitaxel in the treatment of ovarian cancer [Internet]. 2003. Available from: https://www.nice.org.uk/guidance/ta55/chapter/1Guidance. Accessed 5 May 2020

23. Kamat AA, Kim TJ, Landen CN, Lu C, Han LY, Lin YG, et al. Metronomic chemotherapy enhances the efficacy of antivascular therapy in ovarian cancer. Cancer Res. 2007;67(1):281-8. https:// doi.org/10.1158/0008-5472.CAN-06-3282.
24. Rosenberg P, Andersson H, Boman K, Ridderheim M, Sorbe B, Puistola $\mathrm{U}$, et al. Randomized trial of single agent paclitaxel given weekly versus every three weeks and with peroral versus intravenous steroid premedication to patients with ovarian cancer previously treated with platinum. Acta Oncol (Madr). 2002;41(5):418 24. https://doi.org/10.1080/028418602320404998.

25. Markman M, Hall J, Spitz D, Weiner S, Carson L, Van Le L, et al. Phase II trial of weekly single-agent paclitaxel in platinum/ paclitaxel-refractory ovarian cancer. J Clin Oncol. 2002;20(9): 2365-9. https://doi.org/10.1200/JCO.2002.09.130.

26. Sehouli J, Stengel D, Mustea A, Camara O, Keil E, Elling D, et al. Weekly paclitaxel and carboplatin (PC-W) for patients with primary advanced ovarian cancer: results of a multicenter phase-II study of the NOGGO. Cancer Chemother Pharmacol. 2007;61(2):243-50. https://doi.org/10.1007/s00280-007-0466-z.

27. Rose PG, Smrekar M, Fusco N. A phase II trial of weekly paclitaxel and every 3 weeks of carboplatin in potentially platinum-sensitive ovarian and peritoneal carcinoma. Gynecol Oncol. 2005;96(2): 296-300.

28. Katsumata N, Yasuda M, Takahashi F, Isonishi S, Jobo T, Aoki D, et al. Dose-dense paclitaxel once a week in combination with carboplatin every 3 weeks for advanced ovarian cancer: a phase 3, open-label, randomised controlled trial. Lancet. 2009;374(9698): 1331-8.

29. Pignata S, Scambia G, Katsaros D, Gallo C, Pujade-Lauraine E, De Placido S, et al. Carboplatin plus paclitaxel once a week versus every 3 weeks in patients with advanced ovarian cancer (MITO7): a randomised, multicentre, open-label, phase 3 trial. Lancet Oncol. 2014;15(4):396-405.

30.• Clamp AR, James EC, McNeish IA, Dean A, Kim J-W, O’Donnell $\mathrm{DM}$, et al. Weekly dose-dense chemotherapy in first-line epithelial ovarian, fallopian tube, or primary peritoneal carcinoma treatment (ICON8): primary progression free survival analysis results from a GCIG phase 3 randomised controlled trial. Lancet. 2019;394(10214):2084-95. A randomised phase III trial which recruited patients with FIGO stage IC-IV epithelial ovarian cancer and randomly allocated patients into one of 3 groups: 3-weekly carboplatin and paclitaxel, 3-weekly carboplatin with weekly paclitaxel, or both weekly carboplatin and paclitaxel. This trial showed no significant difference in PFS between arms.

31. Chan JK, Brady MF, Penson RT, Huang H, Birrer MJ, Walker JL, et al. Weekly vs. every-3-week paclitaxel and carboplatin for ovarian cancer. N Engl J Med. 2016;374(8):738-48. https://doi.org/10. 1056/NEJMoa1505067.

32. Katsumata N, Yasuda M, Isonishi S, Takahashi F, Michimae H, Kimura E, et al. Long-term results of dose-dense paclitaxel and carboplatin versus conventional paclitaxel and carboplatin for treatment of advanced epithelial ovarian, fallopian tube, or primary peritoneal cancer (JGOG 3016): a randomised, controlled, openlabel trial. Lancet Oncol. 2013;14(10):1020-6.

33. Oken M, Creech R, Tormey D, Horton J, Davis T, McFadden E, et al. Toxicity and response criteria of the eastern cooperative oncology group. Am J Clin Oncol. 1982;5(6):649-55.

34. Gandara DR, Kawaguchi T, Crowley J, Moon J, Furuse K, Kawahara M, et al. Japanese-US common-arm analysis of paclitaxel plus carboplatin in advanced non-small-cell lung cancer: a model for assessing population-related pharmacogenomics. J Clin Oncol. 2009;27(21):3540-6. https://doi.org/10.1200/JCO.2008. 20.8793.

35. Komatsu M, Wheeler HE, Chung S, Low S-K, Wing C, Delaney $\mathrm{SM}$, et al. Pharmacoethnicity in paclitaxel-induced sensory peripheral neuropathy. Clin Cancer Res. 2015;21(19):4337-46. https:// doi.org/10.1158/1078-0432.CCR-15-0133.

36. Markman M, Walker JL. Intraperitoneal chemotherapy of ovarian cancer: a review, with a focus on practical aspects of treatment. J 
Clin Oncol. 2006;24(6):988-94. https://doi.org/10.1200/JCO.2005. 05.2456 .

37. Armstrong DK, Bundy B, Wenzel L, Huang HQ, Baergen R, Lele $\mathrm{S}$, et al. Intraperitoneal cisplatin and paclitaxel in ovarian cancer. $\mathrm{N}$ Eng1 J Med. 2006;354(1):34-43. https://doi.org/10.1056/ NEJMoa052985.

38. Walker JL, Armstrong DK, Huang HQ, Fowler J, Webster K, Burger RA, et al. Intraperitoneal catheter outcomes in a phase III trial of intravenous versus intraperitoneal chemotherapy in optimal stage III ovarian and primary peritoneal cancer: a gynecologic oncology group study. Gynecol Oncol. 2006;100(1):27-32.

39. Walker JL, Brady MF, Wenzel L, Fleming GF, Huang HQ, DiSilvestro PA, et al. Randomized Trial of Intravenous Versus Intraperitoneal Chemotherapy Plus Bevacizumab in Advanced Ovarian Carcinoma: an NRG Oncology/Gynecologic Oncology Group Study. J Clin Oncol. 2019;37(16):1380-90. https://doi.org/ 10.1200/JCO.18.01568 A randomised phase III trial in which patients with FIGO stage II-IV epithelial ovarian cancer were recruited after immediate primary surgery and randomised to receive intravenous or intraperitoneal chemotherapy within one of 3 trial arms. Each arm also received intravenous bevacizumab 3-weekly. The trial showed no significant difference in PFS between intravenous and intraperitoneal arms of therapy.

40. Ohno S, Siddik ZH, Kido Y, Zwelling LA, Bull JMC. Thermal enhancement of drug uptake and DNA adducts as a possible mechanism for the effect of sequencing hyperthermia on cisplatininduced cytotoxicity in L1210 cells. Cancer Chemother Pharmacol. 1994;34(4):302-6. https://doi.org/10.1007/ BF00686037.

41. van de Vaart PJM, van der Vange N, Zoetmulder FA, van Goethem AR, van Tellingen $O$, ten Bokkel Huinink WW, et al. Intraperitoneal cisplatin with regional hyperthermia in advanced ovarian cancer: pharmacokinetics and cisplatin-DNA adduct formation in patients and ovarian cancer cell lines. Eur J Cancer. 1998;34(1):148-54.

42. Van Driel WJ, Koole SN, Sikorska K, SchagenvanLeeuwen JH, Schreuder HWR, Hermans RHM, et al. Hyperthermic intraperitoneal chemotherapy in ovarian cancer. N Engl J Med. 2018;378(3): 230-40 A randomised phase III clinical trial which recruited patients with FIGO stage III epithelial ovarian cancer and randomised at time of delayed primary surgery to receive hyperthermic intraperitoneal chemotherapy (HIPEC) or not. This showed a significant improvement in PFS and OS with HIPEC.

43. Lim MC, Chang S-J, Yoo HJ, Nam B-H, Bristow R, Park S-Y. Randomized trial of hyperthermic intraperitoneal chemotherapy (HIPEC) in women with primary advanced peritoneal, ovarian, and tubal cancer. J Clin Oncol. 2017;35(15_suppl):5520. https:// doi.org/10.1200/JCO.2017.35.15_suppl.5520.

44. Vergote I, Harter P, Chiva L. Is there a role for intraperitoneal chemotherapy, including HIPEC, in the management of ovarian cancer? J Clin Oncol. 2019;37(27):2420-3. https://doi.org/10. 1200/JCO.19.00091.

45. Spriggs DR, Zivanovic O. Ovarian cancer treatment - are we getting warmer? N Engl J Med. 2018;378(3):293-4. https://doi. org/10.1056/NEJMe1714556.

46. Hanahan D, Weinberg RA. Hallmarks of cancer: the next generation. Cell. 2011;144(5):646-74.

47. Ferrara N, Kerbel RS. Angiogenesis as a therapeutic target. Nature. 2005;438(7070):967-74.

48. Dickson S, Bicknell R, Fraser H. Mid-luteal angiogenesis and function in the primate is dependent on vascular endothelial growth factor. J Endocrinol. 2001;168(3):409-16.

49. Perren TJ, Swart AM, Pfisterer J, Ledermann JA, Pujade-Lauraine E, Kristensen $G$, et al. A phase 3 trial of bevacizumab in ovarian cancer. N Engl J Med. 2011;365(26):2484-96. https://doi.org/10. 1056/NEJMoa1103799.

50. Burger RA, Brady MF, Bookman MA, Fleming GF, Monk BJ, Huang $\mathrm{H}$, et al. Incorporation of bevacizumab in the primary treatment of ovarian cancer. N Engl J Med. 2011;365(26):2473-83. https://doi.org/10.1056/NEJMoa1104390.

51. Oza AM, Cook AD, Pfisterer J, Embleton A, Ledermann JA, Pujade-Lauraine E, et al. Standard chemotherapy with or without bevacizumab for women with newly diagnosed ovarian cancer (ICON7): overall survival results of a phase 3 randomised trial. Lancet Oncol. 2015;16(8):928-36.

52.• Tewari KS, Burger RA, Enserro D, Norquist BM, Swisher EM, Brady MF, et al. Final overall survival of a randomized trial of bevacizumab for primary treatment of ovarian cancer. J Clin Oncol. 2019;37(26):2317-28 Recently published OS data from the GOG-218 randomised phase III clinical trial. This trial compared the use of chemotherapy alone, chemotherapy with bevacizumab alongside only or chemotherapy with bevacizumab alongside and continued as maintenance. In patients with incompletely resected FIGO stage III, or FIGO stage IV epithelial ovarian cancer, initial data showed significantly improved PFS with bevacizumab alongside chemotherapy and continued as maintenance. This recently published $O S$ data also showed significantly increased OS in patients with stage IV disease that are treated with bevaciumab alongside chemotherapy and continued as maintenance.

53. du Bois A, Kristensen G, Ray-Coquard I, Reuss A, Pignata S, Colombo N, et al. Standard first-line chemotherapy with or without nintedanib for advanced ovarian cancer (AGO-OVAR 12): a randomised, double-blind, placebo-controlled phase 3 trial. Lancet Oncol. 2016;17(1):78-89.

54. du Bois A, Floquet A, Kim J-W, Rau J, del Campo JM, Friedlander $\mathrm{M}$, et al. Incorporation of pazopanib in maintenance therapy of ovarian cancer. J Clin Oncol. 2014s;32(30):3374-82.

55. Zhou C, Clamp A, Backen A, Berzuini C, Renehan A, Banks RE, et al. Systematic analysis of circulating soluble angiogenesisassociated proteins in ICON7 identifies Tie2 as a biomarker of vascular progression on bevacizumab. Br J Cancer. 2016;115(2): 228-35.

56. Backen A, Renehan AG, Clamp AR, Berzuini C, Zhou C, Oza A, et al. The combination of circulating Ang1 and Tie2 levels predicts progression-free survival advantage in bevacizumab-treated patients with ovarian cancer. Clin Cancer Res. 2014;20(17):454958. https://doi.org/10.1158/1078-0432.CCR-13-3248.

57. Batchelor TT, Sorensen AG, di Tomaso E, Zhang W-T, Duda DG, Cohen KS, et al. AZD2171, a pan-VEGF receptor tyrosine kinase inhibitor, normalizes tumor vasculature and alleviates edema in glioblastoma patients. Cancer Cell. 2007;11(1):83-95.

58. Jayson GC, Zhou C, Backen A, Horsley L, Marti-Marti K, Shaw D, et al. Plasma Tie2 is a tumor vascular response biomarker for VEGF inhibitors in metastatic colorectal cancer. Nat Commun. 2018;9(1): 4672.

59. Ashworth A. A synthetic lethal therapeutic approach: poly(ADP) ribose polymerase inhibitors for the treatment of cancers deficient in DNA double-strand break repair. J Clin Oncol. 2008;26(22):378590. https://doi.org/10.1200/JCO.2008.16.0812.

60. The Cancer Genome Atlas Research Network. Integrated genomic analyses of ovarian carcinoma. Nature. 2011;474(7353):609-15.

61. Mukhopadhyay A, Plummer ER, Elattar A, Soohoo S, Uzir B, Quinn JE, et al. Clinicopathological features of homologous recombination-deficient epithelial ovarian cancers: sensitivity to PARP inhibitors, platinum, and survival. Cancer Res. 2012;72(22):5675-82. https://doi.org/10.1158/0008-5472.CAN$12-0324$. 
62. Bunting SF, Callén E, Wong N, Chen H-T, Polato F, Gunn A, et al. 53BP1 inhibits homologous recombination in Brca1-deficient cells by blocking resection of DNA breaks. Cell. 2010;141(2):243-54.

63. Bryant HE, Schultz N, Thomas HD, Parker KM, Flower D, Lopez E, et al. Specific killing of BRCA2-deficient tumours with inhibitors of poly(ADP-ribose) polymerase. Nature. 2005;434(7035): 913-7.

64. Farmer H, McCabe N, Lord CJ, Tutt ANJ, Johnson DA, Richardson $\mathrm{TB}$, et al. Targeting the DNA repair defect in BRCA mutant cells as a therapeutic strategy. Nature. 2005;434(7035):917-21.

65. Murai J, Huang S -y N, Das BB, Renaud A, Zhang Y, Doroshow $\mathrm{JH}$, et al. Trapping of PARP1 and PARP2 by clinical PARP inhibitors. Cancer Res. 2012;72(21):5588-99. https://doi.org/10.1158/ 0008-5472.CAN-12-2753.

66. Hopkins TA, Shi Y, Rodriguez LE, Solomon LR, Donawho CK, DiGiammarino EL, et al. Mechanistic dissection of PARP1 trapping and the impact on in vivo tolerability and efficacy of PARP inhibitors. Mol Cancer Res. 2015;13(11):1465-77. https://doi.org/10. 1158/1541-7786.MCR-15-0191-T.

67. Patel AG, Sarkaria JN, Kaufmann SH. Nonhomologous end joining drives poly(ADP-ribose) polymerase (PARP) inhibitor lethality in homologous recombination-deficient cells. Proc Natl Acad Sci. 2011;108(8):3406-11. https://doi.org/10.1073/pnas.1013715108.

68. McCormick A, Donoghue P, Dixon M, O’Sullivan R, O’Donnell $\mathrm{RL}$, Murray $\mathrm{J}$, et al. Ovarian cancers harbor defects in nonhomologous end joining resulting in resistance to rucaparib. Clin Cancer Res. 2017;23(8):2050-60. https://doi.org/10.1158/ 1078-0432.CCR-16-0564.

69.• Moore K, Colombo N, Scambia G, Kim B-G, Oaknin A, Friedlander M, et al. Maintenance olaparib in patients with newly diagnosed advanced ovarian cancer. N Engl J Med. 2018;379(26): 2495-505. https://doi.org/10.1056/NEJMoa1810858 A randomised phase III trial of patients with platinum sensitive FIGO stage III/IV high grade serous or endometrioid ovarian carcinoma with $B R C A 1 / 2$ mutation. Patients were randomised to receive either olaparib or placebo as first-line maintance treatment for up to 2 years. This showed a significant improvement in PFS for patients treated with olaparib.

70.• González-Martín A, Pothuri B, Vergote I, DePont Christensen R, Graybill W, Mirza MR, et al. Niraparib in patients with newly diagnosed advanced ovarian cancer. N Engl J Med. 2019: NEJMoa1910962. https://doi.org/10.1056/NEJMoa1910962 A randomised phase III trial which recruited patients with platinum sensitive FIGO stage III-IV high grade serous cancer, regardless of $B R C A$-mutation status, and randomised to receive niraparib or placebo as first-line maintenance therapy for up to 3 years. This trial showed significantly improved PFS in all patients treated with niraparib, with greatest benefit in those with $B R C A$-mutant or homologous recombination deficient (HRD) tumours.

71.• Coleman RL, Fleming GF, Brady MF, Swisher EM, Steffensen KD, Friedlander M, et al. Veliparib with first-line chemotherapy and as maintenance therapy in ovarian cancer. N Engl J Med. 2019: NEJMoa1909707. https://doi.org/10.1056/NEJMoa1909707 A randomised phase III trial recruiting patients with FIGO stage III-IV high-grade serous ovarian cancer, regardless of $B R C A$-mutant or HRD status. Patients were allocated to receive standard platinum-based chemotherapy with either veliparib concurrently, veliparib concurrently and as maintenance, or chemotherapy alone. This trial showed that the PARP inhibitor veliparib was tolerated alongside chemotherapy and that all patients treated with veliparib concurrently with chemotherapy and continued as maintenance had a significantly prolonged PFS.

72. Oza AM, Cibula D, Benzaquen AO, Poole C, Mathijssen RHJ, Sonke GS, et al. Olaparib combined with chemotherapy for recurrent platinum-sensitive ovarian cancer: a randomised phase 2 trial. Lancet Oncol. 2015;16(1):87-97.

73. Popova T, Manie E, Rieunier G, Caux-Moncoutier V, Tirapo C, Dubois $\mathrm{T}$, et al. Ploidy and large-scale genomic instability consistently identify basal-like breast carcinomas with BRCA1/2 inactivation. Cancer Res. 2012;72(21):5454-62. https://doi.org/10.1158/ 0008-5472.CAN-12-1470.

74. Birkbak NJ, Wang ZC, Kim J-Y, Eklund AC, Li Q, Tian R, et al. Telomeric allelic imbalance indicates defective DNA repair and sensitivity to DNA-damaging agents. Cancer Discov. 2012;2(4): 366-75. https://doi.org/10.1158/2159-8290.CD-11-0206.

75. Abkevich V, Timms KM, Hennessy BT, Potter J, Carey MS, Meyer LA, et al. Patterns of genomic loss of heterozygosity predict homologous recombination repair defects in epithelial ovarian cancer. $\mathrm{Br} \mathrm{J}$ Cancer. 2012;107(10):1776-82.

76. Liu JF, Gordon M, Veneris J, Braiteh F, Balmanoukian A, Eder JP, et al. Safety, clinical activity and biomarker assessments of atezolizumab from a phase I study in advanced/recurrent ovarian and uterine cancers. Gynecol Oncol. 2019;154(2):314-22.

77. Hamanishi J, Mandai M, Ikeda T, Minami M, Kawaguchi A, Murayama T, et al. Safety and antitumor activity of anti-PD-1 antibody, nivolumab, in patients with platinum-resistant ovarian cancer. J Clin Oncol. 2015;33(34):4015-22. https://doi.org/10. 1200/JCO.2015.62.3397.

78. Matulonis UA, Shapira-Frommer R, Santin AD, Lisyanskaya AS, Pignata S, Vergote I, et al. Antitumor activity and safety of pembrolizumab in patients with advanced recurrent ovarian cancer: results from the phase II KEYNOTE-100 study. Ann Oncol. 2019;30(7):1080-7.

79. Eskander RN, Ledermann JA, Birrer MJ, Fujiwara K, Gaillard S, Richardson GE, et al. JAVELIN ovarian PARP 100 study design: phase III trial of avelumab + chemotherapy followed by avelumab + talazoparib maintenance in previously untreated epithelial ovarian cancer. J Clin Oncol. 2019;37(8 suppl):TPS9.

80. Strickland KC, Howitt BE, Shukla SA, Rodig S, Ritterhouse LL, Liu JF, et al. Association and prognostic significance of BRCA1/2mutation status with neoantigen load, number of tumor-infiltrating lymphocytes and expression of PD-1/PD-L1 in high grade serous ovarian cancer. Oncotarget. 2016;7(12).

81. Wieser V, Gaugg I, Fleischer M, Shivalingaiah G, Wenzel S, Sprung S, et al. BRCA1/2 and TP53 mutation status associates with PD-1 and PD-L1 expression in ovarian cancer. Oncotarget. 2018;9(25).

82. Liu JF, Barry WT, Birrer M, Lee J-M, Buckanovich RJ, Fleming $\mathrm{GF}$, et al. Combination cediranib and olaparib versus olaparib alone for women with recurrent platinum-sensitive ovarian cancer: a randomised phase 2 study. Lancet Oncol. 2014;15(11):1207-14.

83. Liu JF, Barry WT, Birrer M, Lee J-M, Buckanovich RJ, Fleming $\mathrm{GF}$, et al. Overall survival and updated progression-free survival outcomes in a randomized phase II study of combination cediranib and olaparib versus olaparib in relapsed platinum-sensitive ovarian cancer. Ann Oncol. 2019;30(4):551-7.

84. Kaplan AR, Gueble SE, Liu Y, Oeck S, Kim H, Yun Z, et al. Cediranib suppresses homology-directed DNA repair through down-regulation of BRCA1/2 and RAD51. Sci Transl Med. 2019;11(492):eaav4508. https://doi.org/10.1126/scitranslmed. aav 4508 .

85.• Ray-Coquard I, Pautier P, Pignata S, Perol D, Gonzalez-Martin A, Sevelda P, et al. Phase III PAOLA-1/ENGOT-ov25 trial: olaparib plus bevacizumab (bev) as maintenance therapy in patients (pts) with newly diagnosed, advanced ovarian cancer. Ann Oncol. 2019:851-934 A randomised phase III trial investigating combination therapy with bevacizumab and olaparib in the firstline management of epithelial ovarian cancer. Patients recruited had FIGO stage III-IV high-grade serous or endometrioid ovarian cancer and had responded to platinum- 
taxane chemotherapy with bevacizumab. They were then randomised to continue with bevacizumab alongside either olaparib or placebo. This trial showed increased PFS in patients treated with combination maintenance therapy regardless of HRD status.

86. Stewart RA, Pilié PG, Yap TA. Development of PARP and immune-checkpoint inhibitor combinations. Cancer Res. 2018;78(24):6717-25.

87. Khan KA, Kerbel RS. Improving immunotherapy outcomes with anti-angiogenic treatments and vice versa. Nat Rev Clin Oncol. 2018;15(5):310-24.

88. Fukumura D, Kloepper J, Amoozgar Z, Duda DG, Jain RK. Enhancing cancer immunotherapy using antiangiogenics: opportunities and challenges. Nat Rev Clin Oncol. 2018;15(5):325-40.
89. Pignata S, Lorusso D, Joly F, Gallo C, Colombo N, Sessa C, et al. Chemotherapy plus or minus bevacizumab for platinum-sensitive ovarian cancer patients recurring after a bevacizumab containing first line treatment: The randomized phase 3 trial MITO16BMaNGO OV2B-ENGOT OV17. J Clin Oncol. 2018;36(15_suppl):5506. https://doi.org/10.1200/JCO.2018.36. 15_suppl.5506.

Publisher's Note Springer Nature remains neutral with regard to jurisdictional claims in published maps and institutional affiliations. 